\title{
Chromosomal inversion polymorphism in Drosophila mediopunctata: seasonal, altitudinal, and latitudinal variation
}

\author{
Galina Ananina ${ }^{1}$, Alexandre A. Peixoto ${ }^{2}$, Blanche C. Bitner-Mathé ${ }^{3}$, Wilma N. Souza ${ }^{1}$, Luciano Basso da \\ Silva $^{4}$, Vera L.S. Valente ${ }^{5}$, and Louis B. Klaczko ${ }^{1}$ \\ ${ }^{1}$ Universidade Estadual de Campinas, Instituto de Biologia, Departamento de Genética e Evolução, \\ Campinas, SP, Brazil. \\ ${ }^{2}$ Instituto Oswaldo Cruz, Departamento de Bioquímica e Biologia Molecular, Rio de Janeiro, RJ, Brazil. \\ ${ }^{3}$ Universidade Federal do Rio de Janeiro, Instituto de Biologia, Departamento de Genética, Rio de Janeiro, \\ RJ, Brazil. \\ ${ }^{4}$ Centro Universitário FEEVALE, Instituto de Ciências da Saúde, Novo Hamburgo, RS, Brazil. \\ ${ }^{5}$ Universidade Federal do Rio Grande Sul, Instituto de Biociências, Departamento de Genética, \\ Porto Alegre, RS, Brazil.
}

\begin{abstract}
The most polymorphic chromosome for inversions in Drosophila mediopunctata is the chromosome II, where 17 inversions have been found, eight of which occurring in the distal region and nine in the proximal region. We present an analysis of the chromosome II inversion polymorphism with respect to seasonal, altitudinal and latitudinal variation. In $D$. mediopunctata from the Parque Nacional do Itatiaia (southeastern Brazil), the frequencies of three of the distal inversions (namely $D A, D S$, and $D P$ ) vary seasonally. These inversions also show altitudinal clines in their frequencies. This microgeographic pattern was not observed on a macrogeographic scale. $D$. mediopunctata from Porto Alegre are less polymorphic for inversions than other populations, the most remarkable reduction occurring in the proximal region of chromosome II. There is a considerable difference between $D$. mediopunctata from Campinas and specimens from Serra do Japi, which are separated by only $50 \mathrm{~km}$. In contrast, $D$. mediopunctata from Serra do Japi are much more similar to specimens from the Parque Nacional do Itatiaia, which is $200 \mathrm{~km}$ far.
\end{abstract}

Key words: cline, microgeographic variation, temperature, tripunctata group, Brazil.

Received: April 8, 2003; Accepted: July 28, 2003.

\section{Introduction}

Chromosomal inversion polymorphism in species of Drosophila is one of the best studied systems in population genetics. Inversions have been used to study phylogenies, geographical clines, temporal cycles, meiotic drive, and natural selection (for reviews see Sperlich and Pfriem, 1986; Krimbas and Powell, 1992). Since in a number of species this kind of polymorphism is under selection, it is common to assume a priori that this is true for any species and to conclude that this polymorphism is maintained by balancing selection (Dobzhansky, 1970). However, Krimbas and Loukas (1980), in their review of chromosomal inversion polymorphism in D. subobscura, insisted that one should try to demonstrate which type of selection,

Send correspondence to Louis B. Klaczko. Universidade Estadual de Campinas, Instituto de Biologia, Departamento de Genética e Evolução, Caixa Postal 6109, 13084-971 Campinas, SP, Brazil. E-mail: lbk@unicamp.br. if any, is actually occurring in each case. Thus, the question as to how chromosomal inversion polymorphisms are maintained remains unanswered, especially in very polymorphic species.

Drosophila mediopunctata, a species of the tripunctata group, is very common in many localities in South America, especially during the winter (Saavedra et al., 1995). This species ranges from El Salvador to southern Brazil (Frota-Pessoa, 1954; Val et al., 1981). Various aspects of its biology make $D$. mediopunctata an interesting model for studying the genetics of natural populations (for review and discussion, see Klaczko, 1995).

D. mediopunctata has $2 \mathrm{n}=12$ chromosomes, consisting of five pairs of rods and a pair of dots (Kastritsis, 1966), and is highly polymorphic for inversions. Chromosomes X, II and IV show inversion polymorphisms. We found, in addition to the Standard arrangement, three inversions in chromosome $\mathrm{X}$ and one in chromosome IV (Carvalho et al., 
1989; Klaczko et al., 1990; Peixoto and Klaczko, 1991). Chromosome II is the most polymorphic, with 17 inversions described. Understanding this complexity can be simplified by assigning the inversions to distal and proximal groups, based on the chromosome region in which they occur. The distal group includes eight inversions $(D A, D I, D S$, $D P, D V, D R, D L$, and $D J)$, while the proximal region contains nine ( $P C 0, P C 1, P C 2, P C 3, P C 4, P C 5, P B 0, P A 0$, and PA8) (Peixoto and Klaczko, 1991; Ananina et al., 2002).

In almost all combinations between proximal and distal inversions, there is no overlap between the two regions, although in principle recombination between them can occur. There is intense linkage disequilibrium between distal and proximal inversions, for example, $D A$ is associated with $P A 0$, as shown by the standardized coefficient of linkage disequilibrium (D') which presents a value of 0.98 . Similarly, $D P$ is associated with $P C 0\left(\mathrm{D}^{\prime}=0.97\right)$, and $D S$ with $P C 0\left(\mathrm{D}^{\prime}=0.95\right)$ (Peixoto and Klaczko, 1991; Zapata, 2000).

In this paper, we examine the seasonal, altitudinal, and latitudinal variations in inversion frequencies in $D$. mediopunctata, in an attempt to understand how these polymorphisms are maintained.

\section{Materials and Methods}

\section{Fly samples}

Microgeographic variation in inversion frequencies was studied in the Parque Nacional do Itatiaia, on the slopes of Mantiqueira mountains, in the states of Rio de Janeiro and Minas Gerais, Brazil (22 $25^{\prime}$ S, $44^{\circ} 50^{\prime}$ W). The fauna of this region was described by Barth (1957) and the flora by Brade (1956), who characterized it as a subtropical hygroscopic forest. D. mediopunctata were collected at various points, at altitudes from $700 \mathrm{~m}$ to $1600 \mathrm{~m}$. The greatest distance between collection sites was $6 \mathrm{~km}$. Approximately a dozen fermented banana baits spaced 5 to 15 meters apart were used per site.

Nine field trips were made to Itatiaia, but in only two areas (at $1020 \mathrm{~m}$ and $970 \mathrm{~m}$ ) were specimens collected on all occasions. The collection dates were: fall 1986 (25-26 May), winter 1986 (29-30 September), summer 1987 (25-26 February), fall 1987 (30-31 May, 1-2 June), winter 1987 (28-30 August), spring 1987 (27-29 November), summer 1988 (11-13 March), fall 1988 (28-29 May), and spring 1988 (26-28 November).

Three other localities were chosen for macrogeographic analysis: Mata Santa Genebra (22 $53^{\circ}$ S, $47^{\circ} 04^{\prime}$ W, Campinas, São Paulo), Serra do Japi ( $23^{\circ} 17^{\prime}$ S, $47^{\circ} 00^{\prime}$ W, Jundiaí, São Paulo), and Morro Sant'Ana ( $30^{\circ} 02^{\prime}$ S, 51 $1^{\circ} 13^{\prime}$ W, Porto Alegre, Rio Grande do Sul). Ten field collections were made during the period 1991-2000, four of these in Campinas, three in Serra do Japi, and three in Porto Alegre.

\section{Laboratory procedures}

The inversion frequencies in the D. mediopunctata samples were estimated using the adult male sample and egg sample methods (Arnold, 1981; Klaczko, 1995). The adult sample method consisted of crossing each male collected with two or three virgin females from a homokaryotypic strain. We used strain ITC-229ET, which is homokaryotypic for the haplotype $D I-P B O$ in chromosome II, and is routinely maintained in the UNICAMP and UFRJ laboratories. From each cross, the salivary gland chromosomes of up to eight F1 third instar larvae were analyzed cytologically to determine the male's genotype. The probability of a misidentification for a heterozygous male was negligible (less than $1 \%$ ). In the egg sample method, we analyzed one F1 larva from each collected female.

\section{Weather data used in the correlation analysis}

The climatic variables analyzed included the maximum, minimum, and mean monthly temperatures and precipitation. The hydrometric data was supplied by the Brazilian Agency IBAMA (Instituto Brasileiro do Meio Ambiente e dos Recursos Naturais Renováveis). The hydrometric bulletin contained data for the period from September 1986 to December 1988. The average precipitation per day was calculated for each month of the period.

Unfortunately, no reliable records were available for temperatures within the park during the collecting period. Brade (1956) gives average data covering more than 15 years when the meteorological station in the park was in operation. A comparison of these data with recent temperature data for the town of Itatiaia (http://br.weather.com/ weather/climatology/BRXX0578) shows that they are very similar. However, only the data from Brade (1956) were used in the correlation analysis, because they were considered to be more reliable.

\section{Statistical analysis}

The gene arrangements in the distal region are easily recognized in routine preparations. In contrast, proximal inversions are rather difficult to recognize in different homozygotes (Klaczko et al., 1990). Since the linkage disequilibrium between the distal and proximal inversions is very strong in $D$. mediopunctata (see Peixoto and Klaczko, 1991), we used the distal inversions $D A, D I, D S, D P$, and $D V$ as genetic markers for the haplotypes $D A-P A O$, $D I-P B 0, D S-P C 0, D P-P C 0$, and $D V-P C 0$, which together represent more than $85 \%$ of the total number of haplotypes. This procedure allowed us to pool the egg and male samples, since they were not significantly different, thus substantially increasing the sample size. We must emphasize that in no case (among all the samples analyzed) did we find a significant difference between the frequencies estimated using the adult male method and the egg sample method. 
The correlation between the inversion frequencies and altitude, precipitation and temperature was examined after angular transformation of the chromosomal data.

\section{Results}

\section{Altitudinal and seasonal changes in the inversion frequencies in the Parque Nacional do Itatiaia (microgeographic variation)}

The frequencies of distal inversions in chromosome II, the number of chromosomes analyzed in each period and area of collection, and the weighted average frequencies between collections are reported in Table 1. There was a significant, positive correlation between the frequencies of $D A$ (after angular transformation) and the altitude of the collection site $(r=0.87, p<0.01)$ (Figure 1 , Table 2). The opposite occurred in the case of $D S(\mathrm{r}=-0.86, \mathrm{p}<0.01)$ and $D P(\mathrm{r}=-0.77, \mathrm{p}<0.05)$ (not shown in the graph). When $D S$ and $D P$ were pooled, the negative correlation coefficient with altitude was greater $(\mathrm{r}=-0.91, \mathrm{p}<0.01)$ than for $D S$ (Figure 1, Table 2). Such a grouping makes some biological sense, since the $D S$ and $D P$ inversions are almost completely associated with the proximal inversion $P C 0$ to form the haplotypes $D S-P C 0$ and $D P-P C O$. The $D I$ inversion did not show a significant correlation with altitude $(\mathrm{r}=0.29$, $p>0.05$ ) (Figure 1, Table 2). The correlation coefficients were calculated using the weighted average frequencies between collections, as shown at the bottom of Table 1.

The differences in the inversion frequencies between collections were highly significant $\left(\chi^{2}=74.2\right.$, d.f. $=32$, $\mathrm{p}<0.001$ ). The frequency of $D A$ varied periodically (Figure 2), as it increased in cool months (end of fall and winter) and decreased in hot months (end of spring and summer), but we were unable to fit this to a sinusoidal curve. Nonetheless we could find a quadratic function with very good fit $\left(y=-0.0351 x^{2}+0.1781 x+0.6037 ; r^{2}=0.89 ; p<0.01\right)$. There was a significant negative correlation with temperature $(r=-0.90, p<0.001$, for the average temperature $)$ and precipitation $(\mathrm{r}=-0.75, \mathrm{p}<0.05)$ (Table 2$)$. The inversion $D S$ showed an opposite pattern, since its frequencies increased in the hot months and fell in the cool months. The inversions $D I$ (Figure 3 ) and $D P$ did not vary cyclically, although, when $D P$ was pooled with $D S$, a very clear pattern was observed (Figure 4), and a quadratic function could be successfully adjusted $\left(\mathrm{y}=0.0348 \mathrm{x}^{2}-0.1643 \mathrm{x}+0.6184 ; \mathrm{r}^{2}=\right.$ $0.62 ; \mathrm{p}<0.01)$. The correlation coefficients for the inversion frequencies versus altitude and climatic variables are shown in Table 2. Figure 5 shows the distribution of $D A, D I$ and $D S+D P$ inversion frequencies in relation to the average temperature.

\section{Macrogeographic variation}

D. mediopunctata from Campinas, Serra do Japi, and Porto Alegre were also analyzed. The frequencies of distal inversions in chromosome II are shown in Table 3. In no case were the differences between collections from the same locality significant, even when the collections were separated by over 10 years in Campinas and over nine years in Serra do Japi. The microgeographic pattern seen in the Parque Nacional do Itatiaia was not seen macrogeographically (Table 3). The frequencies of $D S, D P$, and $D V$ were higher in Porto Alegre than at the other sites, whereas the frequency of $D A$ was very low (Figure 6). $D$. mediopunctata from Campinas showed intermediate frequencies for all of these inversions. Thus, the frequencies of $D A$ and $D I$ decreased with latitude, while those of $D S$ and $D P$ increased (Figure 6).

The level of polymorphism decreased from the Parque Nacional do Itatiaia to Porto Alegre. Table 4 shows the expected frequencies of heterozygotes, calculated separately for the distal and proximal regions of chromosome II. This calculation was based on the data from males, for which we were sure of the identification of proximal region inversions. Heterozygosity decreased drastically in the proximal region of chromosome II in the Porto Alegre population, as well as the overall inversion number, which was smaller there than in the other populations studied. The overall inversion number in this population was also less than in the other populations studied. In contrast, the expected heterozygosity in the distal region remained almost unaltered.

\section{Discussion}

Our results provide strong evidence that the frequencies of chromosome II inversions $D A$ and $D S$ vary seasonally in $D$. mediopunctata from Itatiaia. Moreover, these two inversions and $D P$ showed altitudinal clines in their fre-

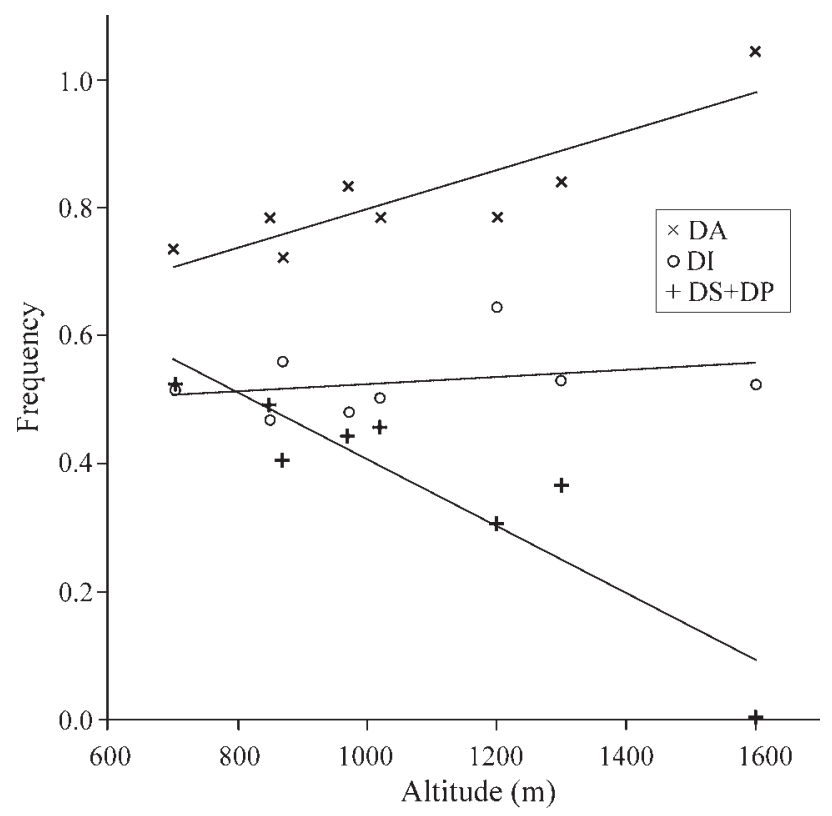

Figure 1-Distribution of $D A, D I$, and $D S+D P$ inversion frequencies in chromosome II of Drosophila mediopunctata in relation to altitude (Parque Nacional do Itatiaia, Brazil) 
Table 1 - Chromosome II inversion frequencies in Drosophila mediopunctata from several collections and altitudes in the Parque Nacional do Itatiaia (southeastern Brazil).

(A)

\begin{tabular}{|c|c|c|c|c|c|c|c|c|c|}
\hline \multirow[b]{3}{*}{ Inv } & \multicolumn{8}{|c|}{ Altitude (m) } & \multirow[b]{3}{*}{ Av } \\
\hline & 1600 & 1300 & 1200 & 1020 & 970 & 870 & 850 & 700 & \\
\hline & \multicolumn{8}{|c|}{ Frequency } & \\
\hline \multicolumn{10}{|c|}{ Fall 1986 May (25-26) } \\
\hline$D A$ & - & 0.500 & - & 0.541 & 0.533 & - & - & - & 0.528 \\
\hline$D I$ & - & 0.308 & - & 0.257 & 0.221 & - & - & - & 0.250 \\
\hline$D S$ & - & 0.058 & - & 0.095 & 0.107 & - & - & - & 0.093 \\
\hline$D P$ & - & 0.096 & - & 0.027 & 0.098 & - & - & - & 0.076 \\
\hline$O T$ & - & 0.038 & - & 0.081 & 0.041 & - & - & - & 0.052 \\
\hline$N$ & - & 52 & - & 74 & 122 & - & - & - & 248 \\
\hline \multicolumn{10}{|c|}{ Winter 1986 September (29-30) } \\
\hline$D A$ & - & 0.750 & - & 0.477 & 0.580 & - & - & - & 0.535 \\
\hline$D I$ & - & 0.125 & - & 0.252 & 0.236 & - & - & - & 0.242 \\
\hline$D S$ & - & 0.125 & - & 0.113 & 0.088 & - & - & - & 0.100 \\
\hline$D P$ & - & 0 & - & 0.072 & 0.052 & - & - & - & 0.060 \\
\hline$O T$ & - & 0 & - & 0.086 & 0.044 & - & - & - & 0.063 \\
\hline$N$ & - & 8 & - & 222 & 250 & - & - & - & 480 \\
\hline \multicolumn{10}{|c|}{ Summer 1987 February (25-26) } \\
\hline$D A$ & 0.750 & 0.571 & 0.500 & 0.425 & 0.398 & - & - & - & 0.438 \\
\hline$D I$ & 0.250 & 0.143 & 0.364 & 0.349 & 0.306 & - & - & - & 0.318 \\
\hline$D S$ & 0 & 0.143 & 0.091 & 0.132 & 0.176 & - & - & - & 0.143 \\
\hline$D P$ & 0 & 0.071 & 0.000 & 0.066 & 0.046 & - & - & - & 0.050 \\
\hline$O T$ & 0 & 0.071 & 0.045 & 0.028 & 0.074 & - & - & - & 0.050 \\
\hline$N$ & 8 & 14 & 22 & 106 & 108 & - & - & - & 258 \\
\hline \multicolumn{10}{|c|}{ Fall 1987 May (30-31), June (1-2) } \\
\hline$D A$ & - & 0 & - & 0.541 & 0.592 & 0.438 & - & 0.456 & 0.537 \\
\hline$D I$ & - & 0.500 & - & 0.239 & 0.206 & 0.281 & - & 0.272 & 0.236 \\
\hline$D S$ & - & 0 & - & 0.077 & 0.101 & 0.063 & - & 0.140 & 0.096 \\
\hline$D P$ & - & 0 & - & 0.055 & 0.048 & 0.094 & - & 0.088 & 0.060 \\
\hline$O T$ & - & 0.500 & - & 0.088 & 0.053 & 0.125 & - & 0.044 & 0.071 \\
\hline$N$ & - & 2 & - & 272 & 228 & 32 & - & 114 & 648 \\
\hline \multicolumn{10}{|c|}{ Winter 1987 August (28-30) } \\
\hline$D A$ & - & 0.611 & - & 0.559 & 0.598 & - & 0.525 & 0.455 & 0.530 \\
\hline$D I$ & - & 0.250 & - & 0.225 & 0.196 & - & 0.229 & 0.237 & 0.224 \\
\hline$D S$ & - & 0.028 & - & 0.118 & 0.103 & - & 0.142 & 0.143 & 0.125 \\
\hline$D P$ & - & 0.028 & - & 0.069 & 0.054 & - & 0.038 & 0.094 & 0.061 \\
\hline$O T$ & - & 0.083 & - & 0.029 & 0.049 & - & 0.067 & 0.071 & 0.060 \\
\hline$N$ & - & 36 & - & 102 & 184 & - & 240 & 224 & 786 \\
\hline \multicolumn{10}{|c|}{ Spring 1987 November (27-29) } \\
\hline$D A$ & - & - & - & 0.424 & 0.549 & - & 0.410 & 0.471 & 0.461 \\
\hline$D I$ & - & - & - & 0.194 & 0.156 & - & 0.224 & 0.147 & 0.188 \\
\hline$D S$ & - & - & - & 0.171 & 0.153 & - & 0.216 & 0.265 & 0.185 \\
\hline
\end{tabular}

quencies. The pattern of clinal variation agreed with the seasonal variation, i.e., the increase in frequency of inversion $D A$ with altitude was similar to that in cool months and the decrease in frequency of inversion $D S$ with altitude was similar to that in hot months. This pattern suggests that temperature or a related variable is the main factor responsible

\begin{tabular}{|c|c|c|c|c|c|c|c|c|c|}
\hline \multirow[b]{3}{*}{ Inv } & \multicolumn{8}{|c|}{ Altitude (m) } & \multirow[b]{3}{*}{$\mathrm{Av}$} \\
\hline & 1600 & 1300 & 1200 & 1020 & 970 & 870 & 850 & 700 & \\
\hline & \multicolumn{8}{|c|}{ Frequency } & \\
\hline$D P$ & - & - & - & 0.129 & 0.076 & - & 0.052 & 0.118 & 0.091 \\
\hline$O T$ & - & - & - & 0.082 & 0.063 & - & 0.097 & 0 & 0.075 \\
\hline$N$ & - & - & - & 170 & 144 & - & 134 & 34 & 482 \\
\hline \multicolumn{10}{|c|}{ Summer 1988 March (11-13) } \\
\hline$D A$ & - & - & - & 0.490 & 0.521 & - & 0.471 & 0.167 & 0.482 \\
\hline$D I$ & - & - & - & 0.186 & 0.188 & - & 0.186 & 0.333 & 0.190 \\
\hline$D S$ & - & - & - & 0.127 & 0.167 & - & 0.157 & 0.167 & 0.146 \\
\hline$D P$ & - & - & - & 0.108 & 0.083 & - & 0.100 & 0 & 0.097 \\
\hline$O T$ & - & - & - & 0.088 & 0.042 & - & 0.086 & 0.333 & 0.084 \\
\hline$N$ & - & - & - & 102 & 48 & - & 70 & 6 & 226 \\
\hline \multicolumn{10}{|c|}{ Fall 1988 May (28-29) } \\
\hline$D A$ & - & - & - & 0.548 & 0.568 & - & 0.534 & - & 0.544 \\
\hline$D I$ & - & - & - & 0.197 & 0.205 & - & 0.172 & - & 0.188 \\
\hline$D S$ & - & - & - & 0.144 & 0.114 & - & 0.149 & - & 0.143 \\
\hline$D P$ & - & - & - & 0.067 & 0.045 & - & 0.075 & - & 0.068 \\
\hline$O T$ & - & - & - & 0.043 & 0.068 & - & 0.069 & - & 0.056 \\
\hline$N$ & - & - & - & 208 & 44 & - & 174 & - & 426 \\
\hline \multicolumn{10}{|c|}{ Spring 1988 November (26-28) } \\
\hline$D A$ & - & - & - & 0.482 & 0.433 & - & 0.513 & - & 0.480 \\
\hline$D I$ & - & - & - & 0.232 & 0.183 & - & 0.179 & - & 0.209 \\
\hline$D S$ & - & - & - & 0.083 & 0.167 & - & 0.154 & - & 0.118 \\
\hline$D P$ & - & - & - & 0.095 & 0.133 & - & 0.103 & - & 0.104 \\
\hline$O T$ & - & - & - & 0.107 & 0.083 & - & 0.051 & - & 0.088 \\
\hline$N$ & - & - & - & 168 & 60 & - & 78 & - & 306 \\
\hline
\end{tabular}

(B) Weighted average frequencies among collections

\begin{tabular}{|c|c|c|c|c|c|c|c|c|c|}
\hline \multirow[b]{3}{*}{ Inv } & \multicolumn{8}{|c|}{ Altitude (m) } & \multirow[b]{3}{*}{$\mathrm{Av}$} \\
\hline & 1600 & 1300 & 1200 & 1020 & 970 & 870 & 850 & 700 & \\
\hline & \multicolumn{8}{|c|}{ Frequency } & \\
\hline \multicolumn{10}{|c|}{ Total } \\
\hline$D A$ & 0.750 & 0.553 & 0.500 & 0.500 & 0.550 & 0.438 & 0.498 & 0.452 & 0.512 \\
\hline$D I$ & 0.250 & 0.259 & 0.364 & 0.233 & 0.213 & 0.281 & 0.204 & 0.241 & 0.224 \\
\hline$D S$ & 0 & 0.063 & 0.091 & 0.116 & 0.119 & 0.063 & 0.161 & 0.153 & 0.126 \\
\hline$D P$ & 0 & 0.062 & 0 & 0.077 & 0.064 & 0.094 & 0.063 & 0.093 & 0.071 \\
\hline$O T$ & 0 & 0.062 & 0.045 & 0.074 & 0.054 & 0.125 & 0.073 & 0.061 & 0.066 \\
\hline$N$ & 8 & 112 & 22 & 1424 & 1188 & 32 & 696 & 378 & 3860 \\
\hline
\end{tabular}

$N$ : number of chromosomes analyzed.

$O T$ : other arrangements.

Av: Average; Inv: Inversions.

for this variation. The almost complete association of $D S$ and $D P$ with the proximal inversion $P C O$ may explain the pattern shown in Figure 5, and why they vary similarly in relation to altitude (Figure 1).

Seasonal variations are prima facie evidence of natural selection (Levitan, 1973). This type of variation is not 
Table 2-Pearson correlation coefficients ( $\mathrm{r}$ ) between inversion frequencies (after angular transformation) in chromosome II of Drosophila mediopunctata and altitude and other climatic data.

\begin{tabular}{llcccc}
\hline Inversion & \multirow{2}{*}{ Altitude } & Precipitation & \multicolumn{3}{c}{ Temperature $\left({ }^{\circ} \mathrm{C}\right)$} \\
\cline { 4 - 6 } & & & Aver. max & Aver. min & Aver. \\
\hline$D A$ & $0.8658^{* *}$ & $-0.7494^{*}$ & $-0.8462^{* *}$ & $-0.9522^{* *}$ & $-0.9006^{* * *}$ \\
$D I$ & 0.2907 & 0.2490 & 0.2978 & 0.1109 & 0.0424 \\
$D S$ & $-0.8598^{* *}$ & 0.3561 & 0.4884 & 0.5897 & 0.5929 \\
$D P$ & $-0.7684^{*}$ & 0.2298 & 0.1480 & 0.4105 & 0.4481 \\
$D S+D P$ & $-0.9133^{* *}$ & 0.3900 & 0.4480 & 0.6503 & $0.6690^{*}$ \\
\hline
\end{tabular}

$*(\mathrm{p}<0.05),{ }^{* *}(\mathrm{p}<0.01),{ }^{* * *}(\mathrm{p}<0.001)$.

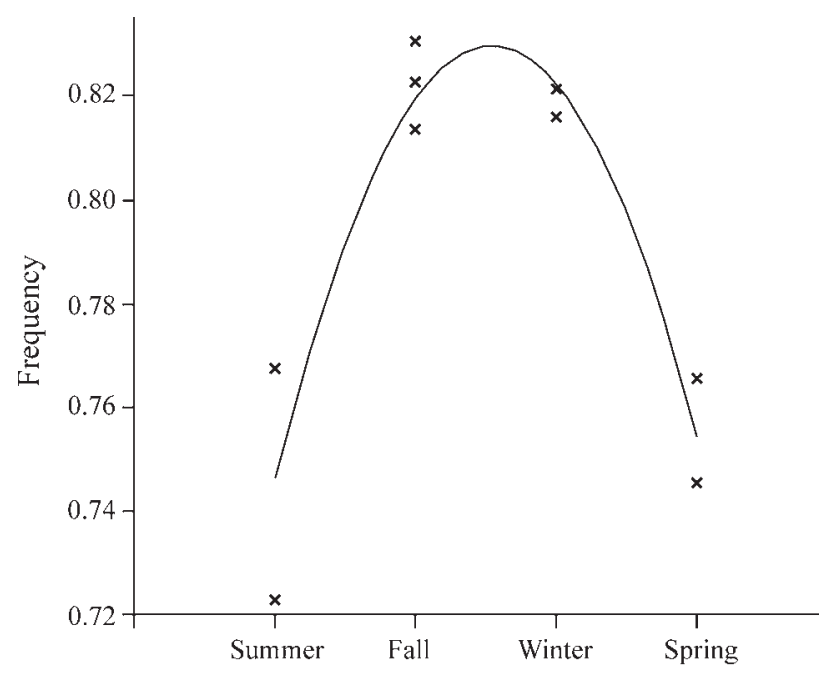

Figure 2-Seasonal variation in the $D A$ inversion frequency in chromosome II of Drosophila mediopunctata (Parque Nacional do Itatiaia, Brazil).

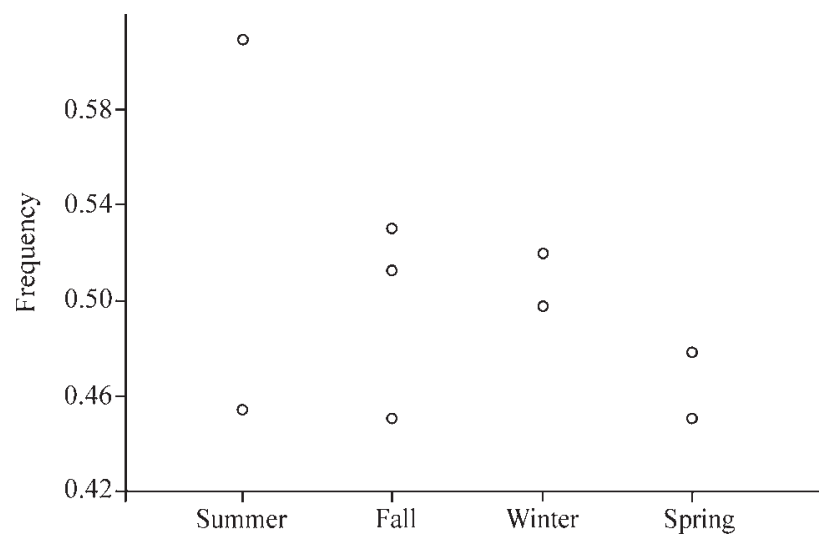

Figure 3-DI inversion frequencies in chromosome II of Drosophila mediopunctata from various collections at the Parque Nacional do Itatiaia, according to the season.

uncommon in chromosomal inversion polymorphisms in species of Drosophila, e. g., D. pseudoobscura (see Dobzhansky, 1948), D. melanica (see Tonzetich and Ward, 1973), D. subobscura (see Fontdevila et al., 1983), but does not occur in all species, e.g., D. pavani (see Brncic, 1973).

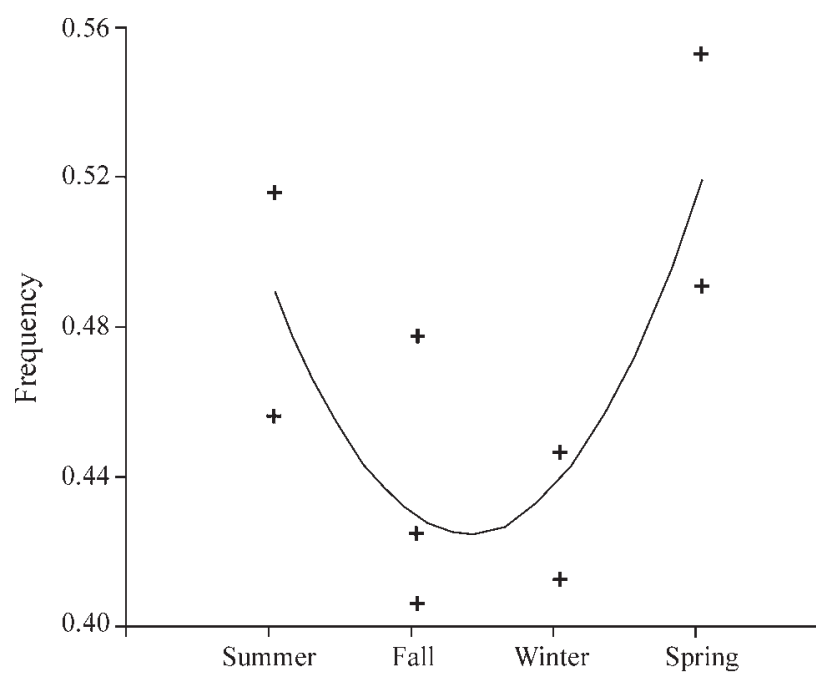

Figure 4-Seasonal variation in the $D S$ and $D P$ (pooled) inversion frequency in chromosome II of Drosophila mediopunctata (Parque Nacional do Itatiaia, Brazil).

Microgeographic variation in inversion frequencies on mountain slopes is also not uncommon in species of Drosophila (Etges, 1984; Burla et al., 1986) and is good evidence of selection.

Seasonal variation has at least two important consequences for chromosomal inversion polymorphism. First, it provides a mechanism that, under certain conditions, permits the maintenance of greater genetic variability in the population. Second, by its effect on chromosomal variability, such variation allows the coexistence of different inversions in the populations for a longer time.

The microgeographic pattern was not observed macrogeographically. The frequency of $D A$ was unexpectedly low in the Porto Alegre population, whereas the frequencies of $D S$ and $D P$ were very high (Figure 6, Table 3). $D$. mediopunctata from Campinas showed intermediate frequencies. However, the limited number of populations examined makes it difficult to conclude that there is a latitudinal cline in the gene arrangement frequencies.

There is extensive data on clinal variations in Drosophila species, including chromosome inversions, allozyme loci, quantitative morphological traits, and physi- 


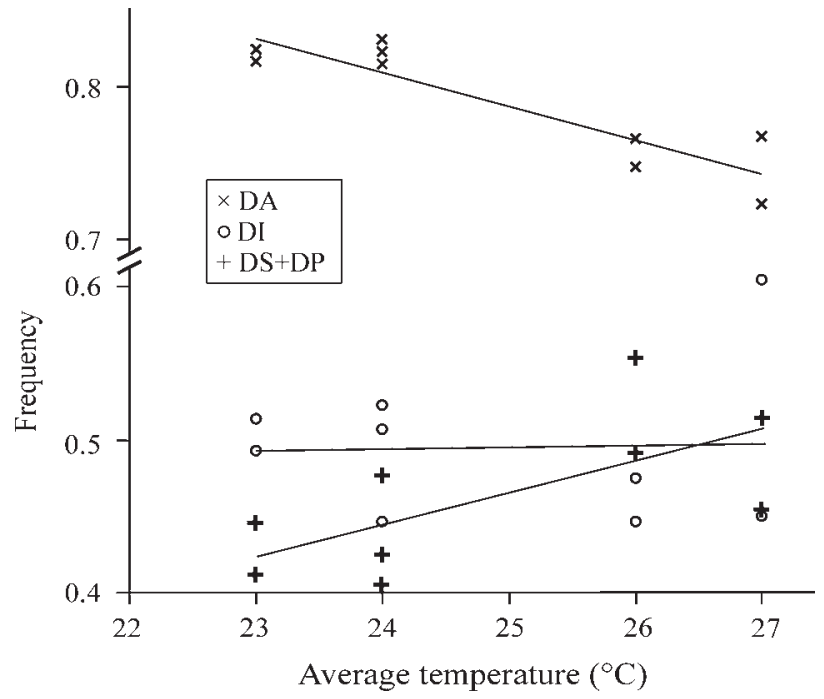

Figure 5-Distribution of $D A, D I$, and $D S+D P$ inversion frequencies in chromosome II of Drosophila mediopunctata in relation to average temperature (Parque Nacional do Itatiaia, Brazil).

Table 3-Frequencies of distal inversions in chromosome II of Drosophila mediopunctata from various localities and collection dates.

\begin{tabular}{|c|c|c|c|c|c|c|c|}
\hline $\begin{array}{l}\text { Population } \\
\text { and date }\end{array}$ & $D A$ & $D I$ & $D S$ & $D P$ & $D V$ & $O T$ & $N$ \\
\hline \multicolumn{8}{|c|}{ Campinas, Mata Santa Genebra } \\
\hline Jun/1991 & 0.217 & 0.044 & 0.359 & 0.348 & 0.032 & 0 & 92 \\
\hline Sep/1996 & 0.228 & 0.080 & 0.377 & 0.204 & 0.098 & 0.012 & 162 \\
\hline Aug/2000 & 0.227 & 0.060 & 0.360 & 0.213 & 0.114 & 0.027 & 150 \\
\hline Sep/2000 & 0.213 & 0.017 & 0.374 & 0.257 & 0.113 & 0.026 & 230 \\
\hline Total & 0.221 & 0.047 & 0.369 & 0.246 & 0.098 & 0.019 & 634 \\
\hline \multicolumn{8}{|c|}{ Serra do Japi } \\
\hline Jun/1994 & 0.505 & 0.122 & 0.170 & 0.090 & 0.069 & 0.043 & 188 \\
\hline Apr/2002 & 0.649 & 0.079 & 0.088 & 0.105 & 0.079 & 0 & 114 \\
\hline May/2002 & 0.576 & 0.030 & 0.182 & 0.091 & 0.091 & 0.030 & 66 \\
\hline Total & 0.562 & 0.092 & 0.147 & 0.095 & 0.076 & 0.027 & 368 \\
\hline \multicolumn{8}{|c|}{ P.Alegre, Morro Santa'Ana } \\
\hline Apr/1999 & 0.083 & 0 & 0.417 & 0.292 & 0.208 & 0 & 24 \\
\hline Oct/1999 & 0.013 & 0 & 0.474 & 0.395 & 0.118 & 0 & 76 \\
\hline May/2000 & 0 & 0 & 0.425 & 0.433 & 0.142 & 0 & 120 \\
\hline Total & 0.014 & 0 & 0.441 & 0.405 & 0.141 & 0 & 220 \\
\hline
\end{tabular}

$N$ : number of chromosomes analyzed

$O T$ : other arrangements.

ological and behavioral traits. Latitudinal clines are generally considered to be a consequence of an adaptive response to different climates. This conclusion is reinforced by the parallelism observed between continents harboring populations with different histories. It seems natural to expect that altitudinal clines should show some parallelism with latitudinal clines, since the same climatic variables have shaped both cline types. However, not all data fit these general ten-
Table 4- Expected heterozygosity for the chromosome in four Brazilian populations of Drosophila mediopunctata.

\begin{tabular}{lcc}
\hline \multirow{2}{*}{ Populations } & \multicolumn{2}{c}{ Heterozygosity } \\
\cline { 2 - 3 } & Distal region & Proximal region \\
\hline Parque Nacional do Itatiaia & 0.666 & 0.657 \\
Serra do Japi & 0.646 & 0.579 \\
Campinas & 0.732 & 0.414 \\
Porto Alegre & 0.615 & 0.024 \\
\hline
\end{tabular}

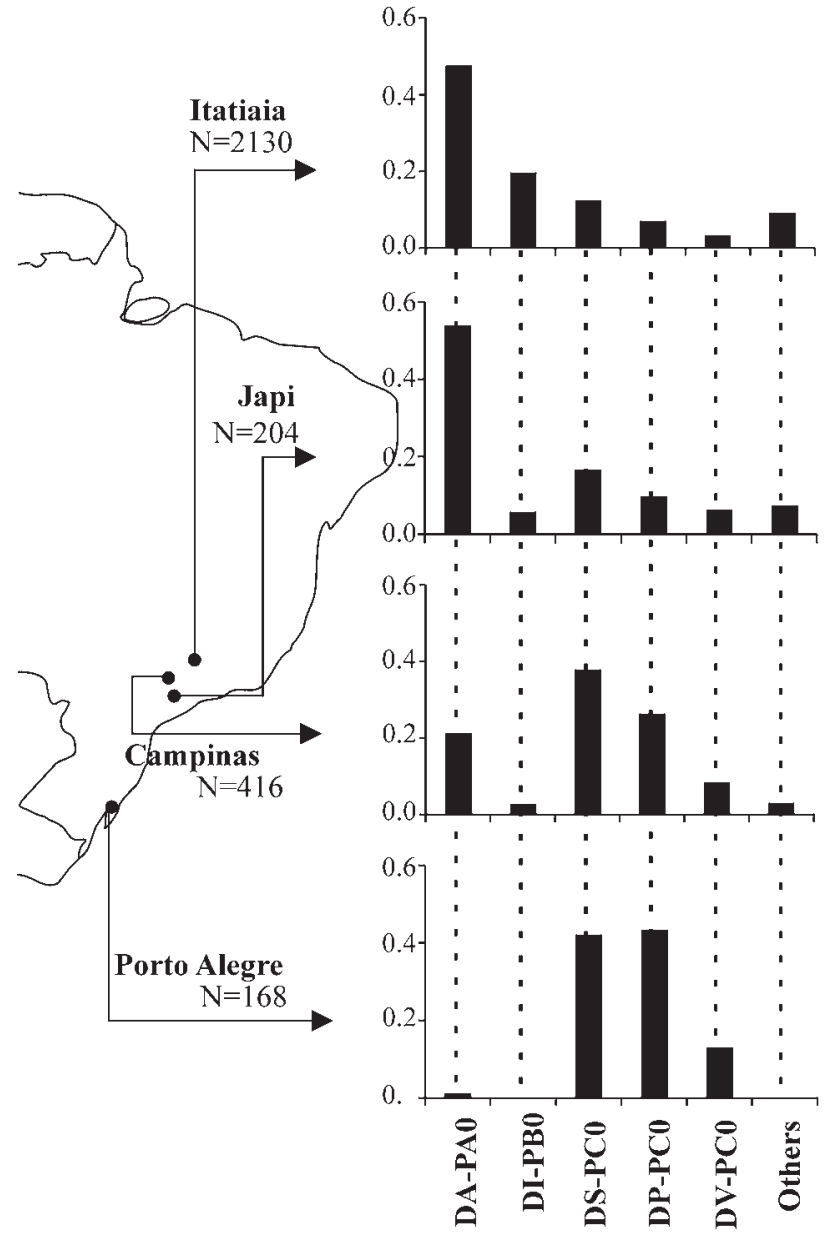

Figure 6-Distribution of haplotype frequencies in Brazilian populations of Drosophila mediopunctata from the Parque Nacional do Itatiaia, Serra do Japi, Campinas, and Porto Alegre. $\mathrm{N}=$ number of chromosomes analyzed.

dencies. For example, the cosmopolitan inversion $\operatorname{In}(2 L) t$ of $D$. melanogaster shows worldwide latitudinal and seasonal fluctuations in frequencies, which are positively correlated with environmental temperature (Van Delden and Kamping, 1991; Kamping and Van Delden, 1999; Van't Land et al., 2000). Laboratory experiments have shown a higher survival of karyotypes possessing $\operatorname{In}(2 L) t$ in relation to high temperature (Kamping and Van Delden, 1999). In contrast, in African populations of D. melanogaster, no lat- 
itudinal or altitudinal trends have been found for this inversion. Significant longitudinal clines have been detected for inversion frequencies, including $\operatorname{In}(2 L) t$, but these are difficult to correlate with a climatic or other ecological factor, and there is nothing to suggest any adaptive interpretation (Aulard et al., 2002).

Another curious example is that of $D$. subobscura. This species is characterized by extensive rich inversion polymorphism that involves all five acrocentric chromosomes. Until 1980, the evidence that inversion polymorphism in D. subobscura was subject to selection was equivocal (Krimbas and Loukas, 1980). Later studies showed north-south geographical clines in gene arrangement frequencies in Europe (Menozzi and Krimbas, 1992). The analysis of the principal components of variance showed that the correlation coefficient between the values of the first principal component for inversions and those of climatic variables (temperature and humidity) was very $\operatorname{high}(\mathrm{p}<0.0001)$. Soon after the invasion of South America (Chile) and North America (western USA and Canada) by D. subobscura in the late 1970s, clines of gene arrangements were formed, as the species spread to the North and to the South (Prevosti et al., 1988). The gradient of the clines increased with time and showed the same pattern as that found in Europe (but reversed in South America on account of the inversion of climatic conditions in the southern hemisphere) (Prevosti et al., 1990). Seasonal changes also exist, but were overlooked in previous studies (RodriguezTrelles et al., 1996; Sole et al., 2002). All of these variations indicate the occurrence of natural selection for gene arrangements in natural populations of this species (Krimbas and Powell, 2000).

The existence of altitudinal variation in the gene arrangement frequencies in D. subobscura is controversial. Altitudinal cline was not found in Chilean populations of $D$. subobscura (Brncic and Budnik, 1987). In Switzerland, Standard gene arrangements of chromosomes $A, I, O$, and $U$ showed a trend that was the opposite of what would be expected if the altitudinal gradients were parallel to the north-south one (Burla et al., 1986). This finding resembles our results for $D$. mediopunctata.

In D. pseudoobscura, Dobzhansky (1943) observed that the altitudinal changes were almost opposite in pattern on a southern Californian mountain (San Jacinto) and the Sierras; gene arrangements more frequent at lower elevations in one mountain range were less frequent in the other. This was later explained assuming the population-specific coadapted nature of the inversions (Krimbas and Powell, 1992).

As shown here, the level of polymorphism decreased from Itatiaia to Porto Alegre. The total number of inversions was lowest in the Porto Alegre population, where only four haplotypes $(D S-P C 0, D P-P C O, D V-P C O$, and $D A-P A 0$ ) were found. The first three of these accounted for more than $98 \%$ of the total. Thus, the proximal region is al- most monomorphic, and is represented by $P C 0$, which is considered ancestral for the region (Peixoto and Klaczko, 1991). Since chromosome II can be divided into two regions according to the inversion groups, it is possible to calculate the expected Hardy-Weinberg heterozygosity for the proximal and distal regions separately. Table 4 shows the expected frequencies of heterozygotes for the proximal and distal regions of chromosome II. Despite the low total number of inversions in the Porto Alegre population, the expected frequency of heterozygotes for the distal region remained almost unaltered, whereas a drastic reduction in polymorphism occurred in the proximal region. The expected frequency of heterozygotes was 0.024 for the proximal region in this population (Table 4). As shown in Table 4, there was a tendency for heterozygosity to decrease from the Parque Nacional do Itatiaia to Porto Alegre, but this was limited to the proximal region. The Porto Alegre population is apparently distinct from the other populations studied, showing peripheral traits. The significance of this finding remains to be clarified.

A decrease in inversion heterozygosity towards the periphery of the species distribution is rather common in species of Drosophila. Soule (1973) cited more than 10 species of Drosophila showing this pattern. For example, African populations of $D$. melanogaster considered to be ancestral are qualitatively more polymorphic than those in the rest of the world (Aulard et al., 2002). There is some disagreement about the explanation for the greater inversion polymorphism seen in central populations. Da Cunha and Dobzhansky (1954) believed that inversions were differentially adapted to various conditions, so that central populations living in a more diverse environment would contain many inversions held in stable equilibrium by natural selection, whereas in marginal environments one arrangement would be most fit because the range of environments was narrow. Carson (1958) stated that peripheral populations were generally very small and suffered for inbreeding, and that natural selection favored "homoselection". Recombination is necessary to promote the formation of new allelic combinations. Whichever explanation is correct, there is little doubt as to the ubiquity of the pattern and the fact that some form of selection must be the causal agent.

The difference between the populations of Serra do Japi and Campinas is interesting, primarily because these areas are separated by only $50 \mathrm{~km}$. Indeed, the population of Serra do Japi was much more similar to that of the Parque Nacional do Itatiaia, $200 \mathrm{~km}$ away (Figure 6). Salis et al. (1995) studied 26 forests in the State of São Paulo and showed that they could be divided into two floristic groups, with the Serra do Japi in one group and the Mata Santa Genebra (Campinas) in the other. Thus, the differences in the inversion frequencies may reflect adaptations to floristic variations. This hypothesis can be tested by col- 
lecting specimens from other localities in the State of São Paulo.

\section{Acknowledgments}

The authors thank Hermes F. Medeiros for help in the field collections and for valuable discussion of manuscript, Aparecida Ramos Libânio, Clea Knauer da Silva, Glória Maria dos Santos, Laércio Santana, for technical support, and Stephen Hyslop for correcting the English. They also want to thank an anonymous referee for a thorough review of the manuscript. This work was supported by grants from Conselho Nacional de Desenvolvimento Científico e Tecnológico $(\mathrm{CNPq})$, Coordenação de Aperfeiçoamento de Pessoal de Ensino Superior (CAPES), Fundação de Amparo à Pesquisa de São Paulo (FAPESP) and Fundo de Apoio ao Ensino e Pesquisa (FAEP-UNICAMP).

\section{References}

Ananina G, Peixoto AA, Souza WN and Klaczko LB (2002) Polytene chromosome map and inversion polymorphism in Drosophila mediopunctata. Mem Inst Oswaldo Cruz 97:691-694.

Arnold J (1981) Statistics of natural-populations. 1. Estimating an allele probability in cryptic fathers with a fixed number of offspring. Biometrics 37:495-504.

Aulard S, David JR and Lemeunier F (2002) Chromosomal inversion polymorphism in Afrotropical populations of Drosophila melanogaster. Genet Res 79:49-63.

Barth R (1957) A fauna do Parque Nacional do Itatiaia. Boletim Parque Nacional do Itatiaia, n. 6. Serviço Florestal, Ministério da Agricultura, Resende, Rio de Janeiro, 150 pp.

Brade AC (1956) A flora do Parque Nacional do Itatiaia. Boletim Parque Nacional do Itatiaia, n. 5. Serviço Florestal, Ministério da Agricultura, Resende, Rio de Janeiro, 96 pp.

Brncic D (1973) Further study of chromosomal-polymorphism in Drosophila pavani. J Hered 64:175-180.

Brncic D and Budnik M (1987) Chromosomal polymorphism in Drosophila subobscura at different elevations in Central Chile. Genetica 75:161-166.

Burla H, Jungen H and Bächli G (1986) Population structure of Drosophila subobscura-nonrandom microdispersion of inversion polymorphism on a mountain slope. Genetica 70:915 .

Carson HL (1958) The population genetics of Drosophila robusta. Adv Genet 9:1-40.

Carvalho AB, Peixoto AA and Klaczko LB (1989) Sex-ratio in Drosophila mediopunctata. Heredity 62:425-428.

Da Cunha AB and Dobzhansky Th (1954) A further study of chromosomal polymorphism in Drosophila willistoni in relation to environment. Evolution 8:119-134.

Dobzhansky Th (1943) Genetics of natural populations. IX. Temporal changes in the composition of populations of Drosophila pseudoobscura. Genetics 28:162-186.

Dobzhansky Th (1948) Genetics of natural populations. XVI. Altitudinal and seasonal changes produced by natural selection in certain populations of Drosophila pseudoobscura and Drosophila persimilis. Genetics 33:158-176.
Dobzhansky Th (1970) Genetics of the evolutionary process. Columbia University Press, New York, 505 pp.

Etges WJ (1984) Genetic-structure and change in naturalpopulations of Drosophila robusta - systematic inversion and inversion association frequency shifts in the Great Smoky Mountains. Evolution 38:675-688.

Fontdevila A, Zapata C, Alvarez G, Sanchez L, Mendez J and Enriquez I (1983) Genetic coadaptation in the chromosomal polymorphism of Drosophila subobscura. I. Seasonalchanges of gametic disequilibrium in a natural-population. Genetics 105:935-955.

Frota-Pessoa O (1954) Revision of the tripunctata group of Drosophila with description of fifteen new species (Drosophilidae, Diptera). Arquivos do Museu Paranaense 10:253-304 + 13 Plates.

Kamping A and Van Delden W (1999) The role of fertility restoration in the maintenance of the inversion $\operatorname{In}(2 L) t$ polymorphism in Drosophila melanogaster. Heredity 83:460-468.

Kastritsis CD (1966) Cytological studies on some species of the tripunctata group of Drosophila. Univ Texas Publs Stud Genet 6615:413-474.

Klaczko LB (1995) Populations genetics of Drosophila mediopunctata. In: Levine L (ed) Genetics of natural populations. The continuing importance of Theodosius Dobzhansky. Columbia University Press, New York, pp 140-153.

Klaczko LB, Otto PA and Peixoto AA (1990) Allele frequency estimates when only heterozygotes can be recognized: method of estimation and application in the case of chromosomal inversion polymorphisms in Drosophila. Heredity 64:263270.

Krimbas CB and Loukas K (1980) The inversion polymorphism in Drosophila subobscura. Evol Biol 12:163-234.

Krimbas CB and Powell JR (1992) Drosophila inversion polymorphism. CRC Press, Boca Raton, FL, 560 pp.

Krimbas CB and Powell JR (2000) Inversion polymorphism in Drosophila. In: Singh RS and Krimbas CB (eds) Evolutionary genetics: from molecules to morphology. v. 1. Cambridge University Press 2000, pp 284-299.

Levitan M (1973) Studies of linkage in populations. 6. Periodic selection for X-chromosome gene arrangement combinations. Evolution 27:215-225.

Menozzi P and Krimbas CB (1992) The inversion polymorphism of Drosophila subobscura revisited: synthetic maps of gene arrangement frequencies and their interpretation. J Evol Biol 5:625-641.

Peixoto AA and Klaczko LB (1991) Linkage disequilibrium analysis of chromosomal inversion polymorphism of Drosophila. Genetics 129:773-777.

Prevosti A, Ribo G, Serra L, Aguade M, Balana J, Monclus M and Mestres F (1988) Colonization of America by Drosophila subobscura: experiment in natural populations that supports the adaptive role of chromosomal-inversion polymorphism. Proc Natl Acad Sci USA 85:5597-5600.

Prevosti A, Serra L, Segarra C, Aguade M, Ribo G and Monclus M (1990) Clines of chromosomal arrangements of Drosophila subobscura in South America evolve closer to Old World patterns. Evolution 44:218-221.

Rodriguez-Trelles F, Alvarez G and Zapata C (1996) Time-series analysis of seasonal changes of the $\mathrm{O}$ inversion polymorphism of Drosophila subobscura. Genetics 142:179-187. 
Saavedra CC, Callegari-Jacques SM, Napp M and Valente VLS (1995) A descriptive and analytical study of Neotropical drosophilid communities. J Zool Syst Evol Res 33:62-74.

Salis SM, Shepherd GJ and Joly CA (1995) Floristic comparison of mesophytic semideciduous forests of the interior of the state of São Paulo, Southeast Brazil. Vegetatio 119:155164.

Sole E, Balany J, Sperlich D and Serra L (2002) Long-term changes in the chromosomal inversion polymorphism of Drosophila subobscura. I. Mediterranean populations from southwestern Europe. Evolution 56:830-835.

Soulé ME (1973) The epistasic cycle: a theory of marginal populations. Annu Rev Ecol Syst 4:165-187.

Sperlich D and Pfriem P (1986) Chromosomal polymorphism in natural and experimental populations. In: Ashburner M, Carson HL and Thompson Jr, JN (eds) The genetics and biology of Drosophila. v. 3a. Academic Press, New York, pp 123-168.
Tonzetich J and Ward CL (1973) Adaptive chromosomal polymorphism in Drosophila melanica. Evolution 27:486-494.

Val FC, Vilela CR and Marques MD (1981) Drosophilidae of the Neotropical Region. In: Ashburner M, Carson HL, and Thompson Jr, JN (eds) The genetics and biology of Drosophila.v. 3a. Academic Press, New York, pp 123-168.

Van Delden W and Kamping A (1991) Changes in relative fitness with temperature among second chromosome arrangements in Drosophila melanogaster. Genetics 127:507-514.

Van't Land J, Van Putten WF, Villarroel H, Kamping A and Van Delden W (2000) Latitudinal variation for two enzyme loci and an inversion polymorphism in Drosophila melanogaster from Central and South America. Evolution 54:201-209.

Zapata C (2000) The D' measure of overall gametic disequilibrium between pairs of multiallelic loci. Evolution 54:18091812. 